\title{
Pandemics in the History of Medicine and Variations of Pharmaceutical Market in Turkey During the Era of the Recent Covid-19 Corona Pandemic
}

\author{
DOI: 10.26466/opus.907864 \\ $*$ \\ Elçin Güven * \\ * Dr, Ersin Inanç Financial Advisory Company, Kırklareli/Turkey \\ E-Mail: elcinguven@windowslive.com ORCID: 0000-0003-0920-0861
}

\begin{abstract}
The concept of Turkish pharmaceutical market may be verbalized as a gradual propagation of economic progresses all over the world together with advancements in medical technologies which was first introduced in the USA after it began to affect the economy by all means considerably which triggered to take some new steps and measures within the framework of globalization in the early 1980's accordingly. Pharmaceutical market, a subgroup of chemical industry, is an integral part of medical services. Pharmaceutical market is quite influential not only on international economy but also on human health. Turkey has advanced technology and manufacturing standards in pharmaceutics. Such expenditures as licensing, patent works, and advance technology manufacturing can be costly in medical market. The main reasons for why the pharmaceutical market grows include easy access to medical services and changes in demographic structure. It is a value-added sector with lots of opportunities to import and export. It is a strategic sector as it offers treatment services and lots of research development activities. In this study, have also been compared the drug market in Turkey, import-made in Turkey, medical products market foreign in the pharmaceutical market rates in Turkey. The concept of Turkish pharmaceutical market has been dealt within this research study initially. Afterwards, import and export rates in Turkey and, medical products market in Turkey have also been included. The purpose of this study is to search for and compare various constituent ingredients of Pharmaceutical Market in Turkey such as the market of Pharmaceutical products in terms of manufacturing and importing such products, the market of medicinal products, the rates of the foreign commerce within the scope of Pharmaceutical Market in Turkey and the related trimester data belonging to the years of 2018-2019 and 2020. The adopted method of this study construe with the findings in respect to the market of medicinal products, the market of manufactured and imported medicinal products, the Pharmaceutical Market and also the foreign trade rates of the medicinal products in Turkey by reflecting such data on tables or diagrams accordingly.
\end{abstract}

Keywords: Covid-19, Pandemics, Turkey Pharmaceutical Market, Turkey Foreign Trade in the Pharmaceutical Market 
ISSN:2528-9527

E-ISSN: 2528-9535

YIl Year: 11

Cilt Volume: 18

Sayı Issue :40

\section{Tip Tarihinde Salgın Hastalıklar ve Covid-19 Döneminde Türkiye İlaç Pazarının Değişimi}

\section{Öz}

1980'ların başında, küreselleşmeyle birlikte, ilk kez ekonomide etkili olan Türkiye ilaç pazarı kavramı, medikal teknolojilerindeki gelişmelerin tüm dünyaya zamanla yayılması olarak ifade edilebilir. Kimya sanayinin alt grubu olan ilaç pazarı ve sektörü, săğlk hizmetlerinin önemli bir parçasıdır. Uluslararası ekonomide ve insanların sağhlğında, ilaç pazarı büyük önem taşımaktadır. Türkiye, ilaç sanayinde gelişmiş bir teknoloji ve üretim standartlarına sahiptir. Ruhsatlandırma, patent çalışmalar ve ileri teknoloji üretimi gibi harcamalar tıbbi pazarda maliyetli olabilir. İlaç pazarının büyümesinin ana nedenleri tıbbi hizmetlere kolay erişim ve demografik yapıdaki değişikliklerdir. Katma değeri yüksek olan ilaç sanayi, ihracat ve ithalat imkânı olan, sektörlerimizden biridir. İlaç pazarı, tedavi hizmetleri sunması, ar-ge faaliyetlerinin çok olması sebebiyle stratejik bir sektördür. Bu çalışmada tıp tarihinde salgin hastalıklar, Türkiye'deki ilaç pazarı, Türkiye'de ithal-imal pazarı, tıbbi ürün pazarı, Türkiye'de ilaç pazarında dış ticaret oranları karşılaştırılmıştır. Çalışmada öncelikle, Türkiye ilaç pazarı kavramı ele alınmıştır. Bu çalışmada amaç, Türkiye'deki ilaç pazarı, Türkiye'de ithal-imal pazarl, tıbbi ürün pazarı, Türkiye'de ilaç pazarında dış ticaret oranlarının 2018-2019-2020 yıllarına ait verileri 3'er aylık periodlarla, karşılaştırmaktır. Çalışmanın yöntemi, 2018-2019-2020 yillarının Türkiye'deki ilaç pazarı, Türkiye'de ithal-imal pazarı, tıbbi ürün pazarı, Türkiye'de ilaç pazarında dış ticaret oranlarının tablolarla değerlendirilip, yorumlanmıştır.

Anahtar Kelimeler: Covid-19, Salgin Hastalıklar, Türkiye İlaç Pazarı, Türkiye İlaç Pazarında Dış Ticaret. 


\section{Introduction}

Such expenditures as licensing, patent works, and advance technology manufacturing can be costly in medical market. The main reasons for why the pharmaceutical market grows include easy access to medical services, changes in demographic structure. While small businesses supply products to national markets; large-scale business enterprises provide products to international companies. Small companies manufacture the goods of small companies in exchange for licensing. Large business enterprises are the ones with an abundance of patents and R\&D investment (Kaynak,2016, p.50). Due to Covid-19, developed countries are facing with unemployment and high rates of inflation due to their expenditure on the treatment of Covid-19 patients and the financial support they provide for the companies (Duran, Acar, 2020, p.57).

Pharmaceutical market is a sector with a highly sustainable demand. Since it concerns human health, it is constantly being supervised. The supervision processes are limited to the public authorities interfering with the prices and to the profitability of the companies. In comparison to other sectors, the process of launching new products might be longer in pharmaceutics. Product launch may take 12 to 13 years once the patent applications are done. Within that period, only one or two out of 10.000 studies will be required eligible in every step of the way. Research and development studies can be around 2 billion Euro in new products. Pharmaceutical market is therefore based on capital and investment. In order to reach an abundance of customers and to boost its efficiency, the pharmaceutics make use of block chain and data processing. Companies who wish to keep operational costs under control try to make use of the selected $R \& D$ methods through various partnerships. As a result, they make a great deal of profit (KPMG, 2020, p.3). Covid-19 pandemic increased the price of shares for pharmaceutical warehouses, pharmaceutical companies, and private medical institutions (Çoban, Coşkun, Çoban, 2020, p.509). Covid-19 resulted some short-term changes in the market including demand, stocking, purchasing, communication, and research \& development. Its long-term effects include progress 
towards self-sufficient supply chains and trends in medication consumption (Ayati, Saiyarsarai, Nikfar 2020, p.800-802).

\section{Pandemics in the History of Medicine}

Ever since 1900s, there have been pandemics with an influence on economy and they are presented hereby.

Epidemics and pandemics are the most dominant disasters among various extreme hazards that human beings have come face to face so far. Their severity, high frequency and infectious properties and devastating effects of contagious diseases globally make them known as "global pandemics" and they are named as pandemics. Those contagious

or infectious diseases namely pandemics which affect the community health care severely have caused deaths of millions of people (Tokaç, 2020). Some of those world-wide known pandemics in the history of mankind are as follows; Spanish Flu 1918-1919-2009-2010, H1N1 Epidemic, Pandemic (Swine Flu), 2003 SARS Pandemic, 2014 Ebola Pandemic, Covid-19 Corona Pandemic.

The Great Influenza (Spanish Flu) 1918-1919: Between 1918 and 1919, the Great Influenza Pandemic (Spanish Flu) caused a social and financial recession with an impact on one third of the world population. With the advent of World War I, the pandemic resulted in the creation of female workforce due to a decrease in male population. Women were granted the right to vote two years after the pandemic. In some countries, there was a rise in the fees of the employees and labor unions got stronger. The Great Influenza Pandemic (Spanish Flu) resulted in women getting socially and financially powerful and triggered movements of change (Bingül, Türk, Ak, 2020, p.192-193).

The Swine Flu H1N1 2009 - 2010: From 2009 to 2010, H1N1 Pandemic (originated in Mexico and known as the Swine Flu) is defined as a flu infection transmitting from swine to humans. It spread all the continents and had a worldwide impact. As it first originated in Mexico, it was initially called as Mexican Flu. Yet, it was later defined as Swine Flu and H1N1 pandemic. In addition to causing death, it also impacted 
agriculture, industry, finance, economics, and medical sectors (Bingül, Türk, Ak, 2020, p.194).

SARS Pandemic in 2003: SARS first appeared on November 16, 2002 in Guangdang State of Southern China. It is defined as acute respiratory failure. In 2003, World Health Organization used its lab resources to prevent the pandemic as soon as possible during the first global SARS pandemic. World Health Organization took the pandemic under control on July 5, 2003. SARS spread to 8098 people in 26 countries and killed 774 people (Eyigün, 2005, p.108). SARS pandemic has an overall mortality rate of about $10 \%$. It is reported to have virulence characteristics with a mortality rate up to 50\% (Cameron et al., 2012). Within scope of the economic effects of SARS, those who are concerned in this issue usually focus on the assessment of the losses the sectors of tourism and retail industry services in Asian countries. The economic shocks experienced in a country lanced spread far and wide in other countries as well both commercially and financially due to the globalization. The SARS Pandemic influenced the economies of China and Hog Kong badly and as a result which the losses of the global economy reached to 40 billion dollars. Therefore, income streams of some oil producing countries such as Venezuela and Kuwait went down because of economic recession globally because the demand for oil and petroleum products at the rate of 300,000 barrels a day in Asia (Türk, Bingül, Ak, 2020, p.623-624).

Ebola Pandemic in 2014: Ebola is a disease with a high mortality rate and potential to spread. It was initially called haemorrhagic fever. In 1976, the first Ebola pandemic was detected in Congo and Sudan. It is an RNA virus with an active filoviridae. Rodents, gorillas, antelopes, and chimps are known to cause infection. African fruit bats are thought to be natural hosts. It can transit from human to (Açıkel, 2014, p.194-195). Ebola mostly affected agriculture, mining, transportation, trading, health, and education sectors in West Africa. Its damage on agriculture in West African countries had an adverse effect on national economies (Yıldırım, 2015). 
Covid-19 Pandemic: Coronavirus ( $\mathrm{CoV})$ is a virus of Orthocoronavirinae subcategory from Coronaviridae family, with an enveloped RNA size varying from $26 \mathrm{~kb}$ to $32 \mathrm{~kb}$. In 2002, SARS-CoV was first seen in China. Later, it spread to the world and resulted in hundreds of deaths by $11 \%$. In 2012, MERSCoV was first seen in Saudi Arabia. It later spread to the whole world with $37 \%$ death rate SARS CoV-2 leading to Covid-19 belongs to the coronavirus family and it causes respiratory failure. World Health Organization named SARS-CoV-2 pandemic as Covid-19. It was declared as a pandemic on March 11, 2020 as it caused the death of more than 4000 people. Covid-19 disease is a respiratory disease first detected in the Wuhan City in December 2019. As of the first case reported in Wuhan, it spread to China and then to the whole world (Çöl, Güneş, 2020, p.1). The disease is infectious. Its clinical symptoms include fever, cough, fatigue, muscle pain and gasping. Covid-19 spreads from person to person through breathing droplets, contact with sick people and surfaces (Samanc1, 2020, p.7). The economic impact of the Covid-19 Pandemic has already resulted in serious and considerable amounts of losses in all sectors of the countries worldwide. Some of the global economic effects the Covid-19 Pandemic are as follows; Ferrari and Volkswagen car companies have already suspended their car manufacturing projects in Europe. Besides, various business sectors such as hotel, transportation, retails, entertainment and restaurants have already faced serious losses and they have already declared losses at the rate of almost one fourth of their GDP deflators. Journeys, travel plans and excursion organizations to tourist attractions and destinations such as Paris, Madrid and Rome came to a standstill and trade fair organizations and similar activities were cancelled. Various meetings and Olympic Games were cancelled and transportation services to certain destinations were restricted for definite periods of time globally (Cinel, 2020, p.128).

\section{Turkish Pharmaceutical Market}

Turkey has advanced technology and manufacturing standards in pharmaceutics. It is a value-added sector with lots of opportunities to import and export. It is a strategic sector as it offers treatment services 
and lots of research development activities. In Turkey, the importance of pharmaceutical market is on the rise. Depending on medical transformation programme and international developments, Turkish pharmaceutical market also changes. Except for the biotechnological products, Turkish pharmaceutical market can produce anything with its advanced technology. "Good manufacturing applications" was designed by WHO and put into effect in 1984. 'Good Manufacturing Applications" were reinforced with technology and infrastructure and it caught up with the European Union countries. International standards are also applied in Turkey and all pharmaceutical manufacturing facilities are supervised by the Ministry of Health. Since 2019, Turkey has been exporting to Commonwealth of Independent States' pharmaceutical market (Middle Eastern and North African Countries, European Union etc.) together with about 180 countries. The top 10 largest pharmaceutical manufacturers are the sellers in Turkish market. Sanofi, Novartis, Roche, and Pfizer are manufacturing in Turkey. The process of producing a medicine may last from 10 to 15 years. Completing all phases and launching a medicine into a market requires research development and investment. This costs around \$ 2.6 billion in pharmaceutical market. According to the General Directorate of R\&D Incentives reporting to the Ministry of Industry and Technology, there are 32 research development centres in pharmaceutical market: 2 in Kırklareli, 8 in Tekirdağ, 13 in Istanbul, 3 in Kocaeli, Ankara, Konya and Balıkesir. Some members of international drug administration council members include Japan, the US, Switzerland, Ireland, Australia, England, Germany, and Canada. As of 2018, Turkish Institution of Drugs and Medical Devices was accepted as a member to International Drug Administration. Any supervision conducted is international recognized. International Compliance Council was founded by the drug authorities in Japan, the US and EU in 1990. International Compliance Council aims at guaranteeing the safety, quality and effectiveness of the medication and international regulation compliance as well as managing and leading. Turkey was granted a full membership to International Compliance Council in 2020. Within that scope, medical devices and clinical studies licensed with a membership of International Compliance Council are considered as approved with 
international standards. (İlaç ve Eczacıllk Ürünleri Sektörü (Ticaret Bakanlığ1), 2020, p.4-5).

\section{Pharmaceutical Market in Turkish Economy}

Pharmaceutical sector is in the chemical sector of manufacturing industry. In terms of strategy and economics, pharmaceutical sector is quite important not only in Turkey but also in the world. In case of pandemics and epidemics, countries with a pharmaceutical market make profit as they can meet the demand. Having a powerful pharmaceutical manufacturing capacity will contribute to the economy and research development projects. Qualified staff members in the Turkish pharmaceutical sector will keep the research development enterprises alive and will contribute to the growth of economics and industry. Turkish pharmaceutical industry can manufacture any product other than the ones require customized manufacturing technology. As in European countries, Turkish market also follows international standards and pharmaceutical sector is dense in Marmara and Trakya regions due to the abundant number of health institutions, communication and transportation opportunities, easy access to staff and supplies (TOBB, 2008, p.1-2).

During Covid-19, changes in demand soon occurred in the pharmaceutical market, communication, and research development. Stocks for certain medications such as the ones relating to immunity and chronic diseases are on the decrease. Despite the increase in the overall demand, the sector generally shrank. Pharmaceutical sector includes making contracts in relevant countries to prepare protocols for medication, as well as to develop, manufacture and distribute medication (Zeren, Boynukısa, 2020, p.31).

Research Development works in the pharmaceutics also include the studies relating to the discovery of a new molecule. New drugs and treatment methods are developed because of studies based on clinical trials, experiments, and combinations. The basic feature that sets pharmaceutical research development projects apart is the participation of humans in clinical trials. Finding molecules and areas of use, restudying the adverse effects of medications and clinical studies of 
research development projects may be costly and time-consuming. Once the molecules are discovered, they are improved to be used as a treatment by the patent owners. Molecules with licensing and patent duration expired are manufacturing by companies of equivalent nature and distributed to a wide range of consumers. Equivalent and generic medication is the basic area of activity for pharmaceutical industry in Turkey. Different dosages of discovered molecules, combinations of 2 or 3 are conducted to develop generic/equivalent products. There has been no molecule developed in Turkey, yet. Research development expenses for basic pharmaceutical products and the production of pharmaceutics related supplies increased $43 \%$ in 2017, in comparison to previous year. Service and product manufacturing in internationally competitive markets constitute the basic elements for the development of pharmaceuticals. To boost these elements, there should be more support for research development activities. International and national pharmaceutical companies have been actively carrying out their clinical trials in our country. The Ministry of Health published "Regulation on Clinical Research" dated August 19, 2011 in the Official paper no 28030. It complies with the European Union Directives and the international principles for good clinical applications. As of July 2018, Turkey has had a share of $1.3 \%$ share in the number of worldwide clinical research (310.483). With its number of clinical trials (3.927), Turkey ranks the $13^{\text {th }}$ in Europe and the $23^{\text {rd }}$ in the world. The number of clinical trials in Turkey is 1177 (except for the trials completed, terminated, or withdrawn) (İlaç Sektörü Raporu, 2019, p.14-15). While Covid-19 hit certain sectors deeply, some managed to make profits. For instance, such sectors as online shopping, cleaning products, masks, distant learning are on the rise whereas there is a decrease in others such as transportation, hotel management and entertainment. During Covid-19, all sectors are being influenced in line with their financial contribution to the economy (Demir, 2020, p.7). Pharmacies have had their economies shrank. There has been an annual drop in doctor visits and a less demand for products and services offered in pharmacies, which might be defined as the main causes of shrinkage. Offering their services to chronically ill patients, pharmacies tr to fill in the gap as a part of a 
system. The sustainability of this function depends on the sustainability of the pharmacies (Türk Eczacılar Birliği, 2020, p.10).

\section{Financial Measures for Covid-19 In Turkey and Selected Countries}

Turkey saved a package of 100 billion lira for Covid-19 period. The package includes food and drinks, accommodation, logistics and transportation, social security premiums for organization and entertainment sectors, postponing withholding, VAT stoppage for 6 months in addition to payments for April, May, and June. Accommodation tax will not be changed until November. Revenue share and servitude costs for hotel rentals in April, May and June were all postponed for 6 months. VAT rates for domestic airline transportation decreased to $1 \%$ for 3 months. Interest payment and principal credit amount were also postposed for at least 3 months and exporters' stocks were determined to be financially supported. Credit Guarantee Fund limit was raised from 25 billion lira to 50 billion liras for small enterprises and firms. Distant and flexible working models were activated. The procedures for short-term working allowance were speeded up. This decreased the costs for the employers whose business was interrupted and provided a temporary income for the employees. The minimum retirement pension became 1500TL and 2 months of compensation period became 4 (Nakiboğlu and Işık, 2020, p.773-774).

Financial measures during Covid-19 pandemic in Spain account for a budget of 8.9 billion Euro (about 0.7 percent of GDP). This budget includes a budget support of 1 billion Euro to the Ministry of Health, 2.8 billion Euro to regional medical services, 110 billion Euro to the additional financing for Covid-10 related medication and vaccination development projects, unemployment compensation right and 300 million Euro for supporting the dependants as additional budget. The US also took measures like the rest of the world and shut down the restaurants, schools, bars and limited travels. As per IMF data, the US issued a Coronavirus Aid and Financial Security Act of 2.3 trillion dollars, which accounts for $11 \%$ of its GDP. This act is made up of following items: 250 billion dollars for increasing unemployment compensations, 24 billion dollars for providing food for the ones who 
cannot afford, 359 billion dollars for supporting small enterprises, 150 billion dollars for state and local administrations, 100 billion dollar for hospitals. Germany saved 156 billion Euro for Covid-19, accounting for about $4.5 \%$ of its GDP. They made expenses to preserve hospital capacity, medical equipment as well as to sustain research and development project for vaccination and to protect freelancers (50 billion Euro grant) and workers. Childcare support and access to public credit guarantees were raised to a minimum of 833 billion Euro, accounting for about $24 \%$ of the GDP. Italy also took some measures during Covid-19. Social security and tax payments in March for all enterprises, freelancers, and taxpayers with a turnover less than 2 million Euro were suspended. Execution, proceedings, tax supervisions, sequestration, field inspections were all postponed till June. Tax reduction applied to medical expenses. Special addition payment to be given to the employees who have an income of less than 40.000 Euro (Özdemir, Atak, Hatıper, 2020, p.193196).

\section{Methods}

Turkey's pharmaceutical market rates compared in tables and figures were reviewed. It has been observed during the literature survey that there is not a comprehensive amount of data and survey regarding to medicinal market, market of pharmaceutical products, variations related to export-import of medicinal products. Within the scope of the survey in question, the researcher and the author of the survey made a move from this point forth and conducted a survey to find out answers to the question of the rates of variations in the market of pharmaceutical products in Turkey and also the variations within this market. Various topics such as Pandemics in the History of Medicine, Variations of Pharmaceutical Market in Turkey, the market of import and manufacturing in Turkey, the market of medicinal products and also the rates of foreign trade within the scope of pharmaceutical products in Turkey have all been searched for, compared and narrated. While devising the tables and diagrams, the medicinal market in Turkey has been dealt with and afterwards the rates of export and import of 
pharmaceutical products and also the rates of medical products have been compared and interpreted in the tables and diagrams.

Table 1. Turkish Pharmaceutical Market (2019)

\begin{tabular}{|c|c|c|c|c|c|c|c|c|c|}
\hline \multicolumn{3}{|c|}{ Total value for 3 months (Billion TL) } & \multicolumn{5}{|c|}{ Total Volume for 3 Months (Billion Boxes) } & \multicolumn{2}{|c|}{ Average Price } \\
\hline Jan- March & 2018 & 2019 & Change & 2018 & 2019 & Change & 2018 & 2019 & Change \\
\hline $\begin{array}{l}\text { Pharmaceutical } \\
\text { Market }\end{array}$ & 7,4 & 9,5 & $\% 27,5$ & 0,6 & 0,6 & $\% 0,4$ & 11,8 & 15 & $\% 27$ \\
\hline \multicolumn{3}{|c|}{ Total value for 6 months (Billion TL) } & \multicolumn{5}{|c|}{ Total Volume for 6 Months (Billion Boxes) } & \multicolumn{2}{|c|}{ Average Price } \\
\hline Jan- June & 2018 & 2019 & Change & 2018 & 2019 & Change & 2018 & 2019 & Change \\
\hline $\begin{array}{l}\text { Pharmaceutical } \\
\text { Market }\end{array}$ & 14,8 & 19,4 & $\% 30,5$ & 1,16 & 1,18 & $\% 1,1$ & 12,8 & 16,5 & $\% 29$ \\
\hline \multicolumn{3}{|c|}{ Total value for 9 months (Billion TL) } & \multicolumn{5}{|c|}{ Total Volume for 9 Months (Billion Boxes) } & \multicolumn{2}{|c|}{ Average Price } \\
\hline Jan- Sept & 2018 & 2019 & Change & 2018 & 2019 & Change & 2018 & 2019 & Change \\
\hline $\begin{array}{l}\text { Pharmaceutical } \\
\text { Market }\end{array}$ & 22,7 & 29,5 & $\% 30,2$ & 1,72 & 1,74 & $\% 1,3$ & 13,2 & 16,9 & $\% 28,6$ \\
\hline
\end{tabular}

Resource: İeis, 2019, p.2

Turkish pharmaceutical market in January, February and March 2019 became 9.5 billion TL with a total $27.5 \%$ increase in hospitals and pharmacies. The number of boxes sold was 0,6 billion with $0.4 \%$ growth. Average price per box used to be 11,8 TL in the first 3 months of 2018 and it increased up to $15 \mathrm{TL}$ with $27 \%$ in 2019. In the first half of 2019, Turkish pharmaceutical market became 19,4 billion TL in total with $30.5 \%$ increase in hospital and pharmacies. The number of boxes sold was 1.18 billion with $1.1 \%$ growth. In the first 6 months of 2018, average price per box used to be $12.8 \mathrm{TL}$ and it reached up to $16.5 \mathrm{TL}$ with $29 \%$ increase in 2019. In the first 9 months of 2019, Turkish pharmaceutical market became 29.5 billion TL in total with $30.2 \%$ increase in hospital and pharmacies. The number of boxes sold was 1.74 billion with 1.3\% growth. In the first 9 months of 2018, average price per box used to be 13.2 TL and it reached up to 16.9 TL with $28.6 \%$ increase in 2019 .

In Turkish pharmaceutical market, there was $29.9 \%$ increase from January-March 2019 to 2020 and in total volume-box scale, 0.63 billion boxes were sold in 2019 and 0.67 billion boxes were sold in 2020. There was a $6.5 \%$ growth in box sales and the average price per box used to be 15 TL during 2019 Jan-March period and became 18.3 TL during 2019. 
Table 2. Turkish Pharmaceutical Market (2020)

\begin{tabular}{|c|c|c|c|c|c|c|c|c|c|c|}
\hline \multicolumn{4}{|c|}{ Total value for 3 months (Billion TL) } & \multicolumn{5}{|c|}{ Total Volume for 3 Months (Billion Boxes) } & \multicolumn{2}{|c|}{ Average Price } \\
\hline Jan- March & & 2019 & 2020 & Change & 2019 & 2020 & Change & 2019 & 2020 & Change \\
\hline $\begin{array}{l}\text { Pharmaceutical } \\
\text { Market }\end{array}$ & \multicolumn{2}{|r|}{9,4} & 12,3 & $\% 29,9$ & 0,63 & 0,67 & $\% 6,5$ & 15 & 18,3 & $\% 22$ \\
\hline \multicolumn{4}{|c|}{ Total value for 6 months (Billion TL) } & \multicolumn{5}{|c|}{ Total Volume for 6 Months (Billion Boxes) } & \multicolumn{2}{|c|}{ Average Price } \\
\hline Jan- June & & 2019 & 2020 & Change & 2019 & 2020 & Change & 2019 & 2020 & Change \\
\hline $\begin{array}{l}\text { Pharmaceutical } \\
\text { Market }\end{array}$ & & 19,4 & 22,5 & $\% 16,3$ & 1,18 & 1,10 & $\%-6,4$ & 16,5 & 20,5 & $\% 24,3$ \\
\hline \multicolumn{4}{|c|}{ Total value for 9 months (Billion TL) } & \multicolumn{5}{|c|}{ Total Volume for 9 Months (Billion Boxes) } & \multicolumn{2}{|c|}{ Average Price } \\
\hline Jan-September & 2019 & & & Change & & 2020 & Change & 2019 & 2020 & Change \\
\hline $\begin{array}{l}\text { Pharmaceutical } \\
\text { Market }\end{array}$ & 29,5 & & & $\% 17,4$ & & 1,62 & $\%-7,1$ & 16,9 & 21,4 & $\% 26,4$ \\
\hline
\end{tabular}

Resorce: İeis, 2020, p.2

The change ratio rose up to $22 \%$. Turkish pharmaceutical market had a total of $6.4 \%$ decrease in the first six months of the year in hospital and pharmacies; and 1.10 billion boxes were sold, and the market became 22.5 billion TL 2ith 16.3\% in value. During January- June 2019, average price per unit was $16.5 \mathrm{TL}$ in the first 6 months and it increased up to $20.5 \mathrm{TL}$ with $24.3 \%$ increase in 2020 . When the first nine months of 2019 is compared to the first nine months of 2020 , there seems to be a growth of $17,4 \%$. And in terms of average prices, a growth of $26,4 \%$ is recorded.

Table 3. Imported-Manufactured Medication (2019)

\begin{tabular}{|c|c|c|c|c|c|c|c|c|c|}
\hline \multicolumn{3}{|c|}{ Total value for 3 months (Billion TL) } & \multicolumn{5}{|c|}{ Total Volume for 3 Months (Billion Boxes) } & \multicolumn{2}{|c|}{ Average Price } \\
\hline & 2018 & 2019 & Change & 2018 & 2019 & Change & 2018 & 2019 & Change \\
\hline Imported & 3,7 & 4,6 & $\% 22,2$ & 0,1 & 0,1 & $\%-8,9$ & 37 & 49,7 & $\% 34,1$ \\
\hline Manufactured & 3,7 & 4,9 & $\% 33,1$ & 0,5 & 0,5 & $\% 2,2$ & 6,9 & 9 & $\% 30,2$ \\
\hline \multicolumn{8}{|c|}{ Total value for 6 months (Billion TL) } & \multicolumn{2}{|c|}{ Average Price } \\
\hline & 2018 & 2019 & Change & 2018 & 2019 & Change & 2018 & 2019 & Change \\
\hline Imported & 7,6 & 9,5 & $\% 24,5$ & 0,19 & 0,17 & $\%-9,2$ & 40,3 & 55,3 & $\% 37,1$ \\
\hline Manufactured & 7,2 & 9,9 & $\% 36,8$ & 0,97 & 1,01 & $\% 3,1$ & 7,4 & 9,9 & $\% 32,6$ \\
\hline \multicolumn{3}{|c|}{ Total value for 9 months (Billion TL) } & \multicolumn{5}{|c|}{ Total Volume for 9 Months (Billion Boxes) } & \multicolumn{2}{|c|}{ Average Price } \\
\hline & 2018 & 2019 & Change & 2018 & 2019 & Change & 2018 & 2019 & Change \\
\hline Imported & 11,4 & 14,3 & $\% 24,5$ & 0,25 & 0,23 & $\%-9,1$ & 45,2 & 61,9 & $\% 37$ \\
\hline Manufactured & 11,2 & 15,3 & $\% 36$ & 1,47 & 1,51 & $\% 3,1$ & 7,6 & 10,1 & $\% 32$ \\
\hline
\end{tabular}

Resource: Ieis, 2019, p.4

During 2018 January - March, the value and volume of imported medication had $22 \%$ growth and $8.9 \%$ shrinkage, respectively. As of the first 3 months in 2019, the value of imported medication was 4.6 billion TL and its volume accounted for the sales of 0.1 billion boxes with an 
average price of 49.7 TL. Manufactured medication was 4.9 billion TL during 2019 January- March with 0.5 billion boxes sold and the average price per box 9 TL. During 2019 January-June period, imported medication had a $24.5 \%$ of growth value and $9.2 \%$ shrinkage in volume. During the first 6 months, imported medication had a value of 9.5 billion TL and a volume of 0.17 billion boxes sold and an average price of 55.3 TL. Manufactured medication had a value of 9.9 billion TL and 1.01 billion boxes sold with an average price of 9.9 TL during Jan-June period. During the first 9 months of 2019, the imported medication had $24.5 \%$ growth in value and $9.1 \%$ shrinkage in volume. In the first 9 months, imported medication had a value of 14.3 billion TL, 0.23 billion boxes sold in volume with an average price of 61.9 TL. During the first 9 months, imported medication had a growth of $36 \%, 1.51$ billion boxes sold with an average price of $10.1 \mathrm{TL}$.

Table 4. Imported-Manufactured Medication (2020)

\begin{tabular}{|c|c|c|c|c|c|c|c|c|c|}
\hline \multicolumn{3}{|c|}{ Total value for 3 months (Billion TL) } & \multicolumn{5}{|c|}{ Total Volume for 3 Months (Billion Boxes) } & \multicolumn{2}{|c|}{ Average Price } \\
\hline & 2019 & 2020 & Change & 2019 & 2020 & Change & 2019 & 2020 & Change \\
\hline Imported & 4,3 & 5,6 & $\% 28$ & 0,07 & 0,07 & $\%-1,7$ & 60,7 & 79,1 & $\% 30,3$ \\
\hline Manufactured & 5,1 & 6,7 & $\% 31,5$ & 0,56 & 0,60 & $\% 7,5$ & 9,1 & 11,2 & $\% 22,3$ \\
\hline \multicolumn{3}{|c|}{ Total value for 6 months (Billion TL) } & \multicolumn{5}{|c|}{ Total Volume for 6 Months (Billion Boxes) } & \multicolumn{2}{|c|}{ Average Price } \\
\hline & 2019 & 2020 & Change & 2019 & 2020 & Change & 2019 & 2020 & Change \\
\hline Imported & 9,1 & 10,8 & $\% 19,4$ & 0,13 & 0,13 & $\%-5,8$ & 67,1 & 85,1 & $\% 26,8$ \\
\hline Manufactured & 10,3 & 11,7 & $\% 13,5$ & 1,04 & 0,97 & $\%-6,5$ & 9,9 & 12 & $\% 21,4$ \\
\hline \multicolumn{3}{|c|}{ Total value for 9 months (Billion TL) } & \multicolumn{5}{|c|}{ Total Volume for 9 Months (Billion Boxes) } & \multicolumn{2}{|c|}{ Average Price } \\
\hline & 2019 & 2020 & Change & 2019 & 2020 & Change & 2019 & 2020 & Change \\
\hline Imported & 13,8 & 16,9 & $\% 22,2$ & 0,20 & 0,19 & $\%-4$ & 68,8 & 87,6 & $\% 27,2$ \\
\hline Manufactured & 15,7 & 17,7 & $\% 13,1$ & 1,54 & 1,43 & $\%-7,5$ & 10,2 & 12,4 & $\% 22,3$ \\
\hline
\end{tabular}

Resource: Ieis, 2020, p.4

In 2020, it was observed that there was $28 \%$ growth in imported medication and $31.5 \%$ growth in manufactured medication. In total volume box sales, there was a shrinkage of -1.7 in imported medication and a growth of 7.5 in imported medication. There was 30.3\% growth in the average price of imported medication and $22.3 \%$ growth in manufactured medication. There was $5.8 \%$ decrease in imported medication and $6.5 \%$ shrinkage in manufactured medication. In terms of value scale, imported medication had $19.4 \%$ increase and a sale of 10.8 billion TL and manufactured medication had $13.5 \%$ increase and a sale of 11.7 billion TL. In terms of average price level, the average price per box 
was $85.1 \mathrm{TL}$ for imported medication and $12 \mathrm{TL}$ for manufactured medication. Figures points out that there was a growth of $22,2 \%$ in imported medication and $13,1 \%$ in manufactured medication during the first nine months of 2019 and 2020. In terms of average price, there was a growth of $27,2 \%$ in imported medication and $22,3 \%$ in manufactured medication for the same period.

Turkish medical products market includes cosmetics, derma cosmetics, nutritional supplements, biocidal products licensed by the Ministry of Health, vitamins licensed by the Ministry of Agriculture and Forestry, enteral nutrition and medical nutrition, certain medical devices in pharmaceutical form, medical products in pharmaceutical companies, non-pharmacologic products, and formula. During Jan-March 2019, there was $28 \%$ growth in comparison to the same period in 2018 and its value became 723 million TL. Its volume became 45.7 million with $1.2 \%$ increase and its average price was 15.8 TL. In 2019, of nonpharmacologic products with a volume of 45.7 million boxes; 31.1 million (68\% share) belongs to enteral nutrition and medical nutrition. The average price for such products subject to reference price system like medication licensed by the Ministry of Health is $10.00 \mathrm{TL}$. Therefore, it is influential in setting the average price of medical products as $15.8 \mathrm{TL}$. The average price of nutritional supplements was 31.8 TL in 2019 and the average price of formulas was 35.0 TL. In the first half of 2019, it had $27,8 \%$ growth in comparison to the same period in the previous year and a value of $1.439,9$ million TL, $0.3 \%$ increase in boxes with a volume of 87.2 million box volume. The average price of these products is $16,5 \mathrm{TL}$. In the first 9 months of 2019, the value became 2.218,1 million TL with $26.3 \%$ growth and $0,5 \%$ increase in boxes with a volume of 132.7 million box volume. The average price of these products is $16,7 \mathrm{TL}$.

In the first 3 months of 2020, the value became 1.104 million TL with $53 \%$ growth and $20,9 \%$ increase in boxes with a volume of 55.1 million box volume. The average price of these products is $20 \mathrm{TL}$. In 2020, of non-pharmacologic products with a volume of 55.1 million boxes; 35.1 million (64\% share) belongs to enteral nutrition and medical nutrition. 
Table 5. Turkish Medical Products Market (2019)

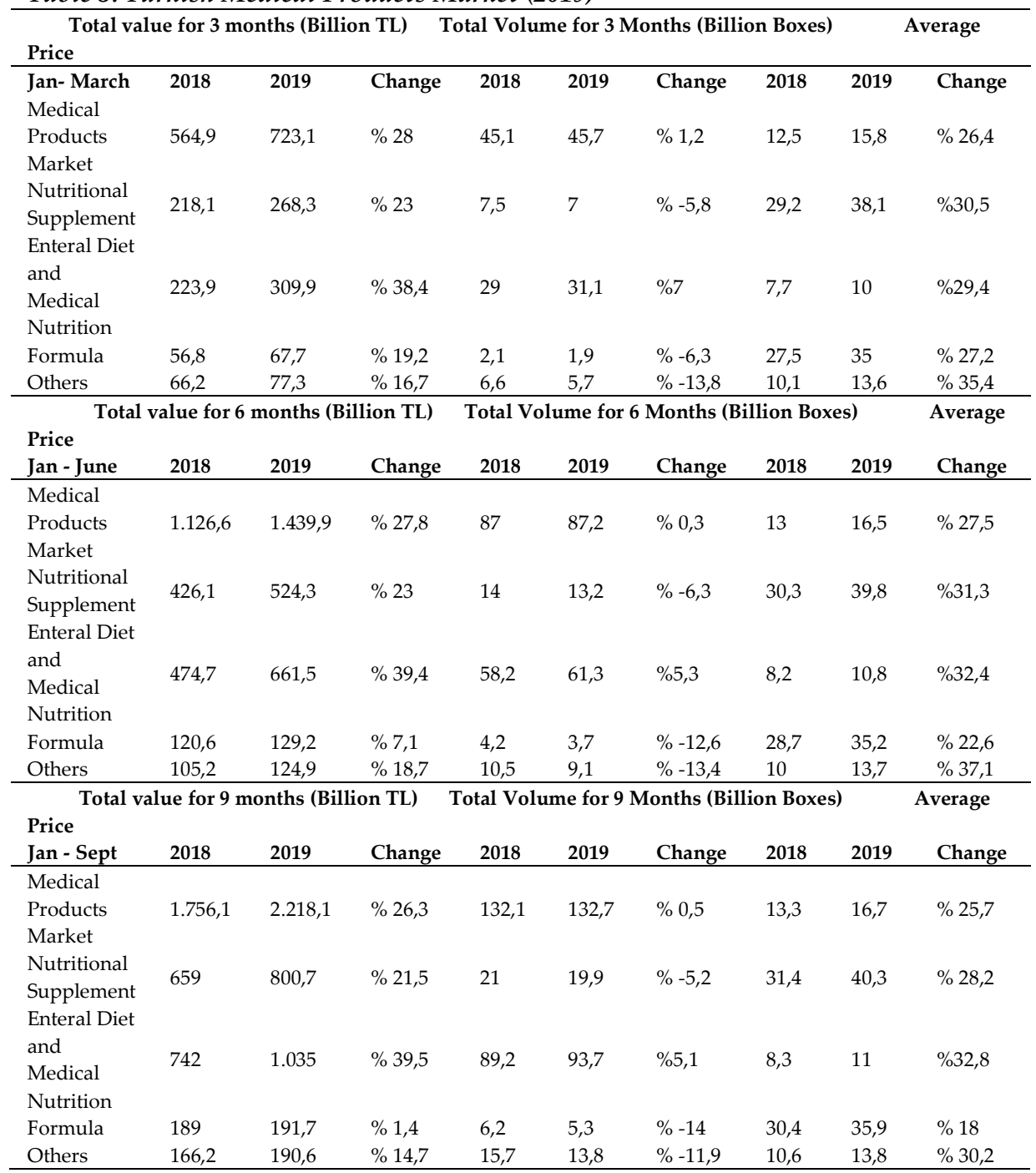

Resource: İeis, 2019, p.5 
Table 6. Turkish Medical Products Market (2020)

\begin{tabular}{|c|c|c|c|c|c|c|c|c|c|}
\hline \multicolumn{4}{|c|}{$\begin{array}{l}\text { Total value for } 3 \text { months (Billion TL) } \\
\text { Average Price }\end{array}$} & \multicolumn{6}{|c|}{ Total Volume for 3 Months (Billion Boxes) } \\
\hline $\begin{array}{l}\text { Jan- March } \\
\text { Medical }\end{array}$ & 2019 & 2020 & Change & 2019 & 2020 & Change & 2019 & 2020 & Change \\
\hline $\begin{array}{l}\text { Products } \\
\text { Market }\end{array}$ & 722 & 1.104 & $\% 53$ & 45,6 & 55,1 & $\% 20,9$ & 15,8 & 20,0 & $\% 26,5$ \\
\hline $\begin{array}{l}\text { Nutritional } \\
\text { Supplement }\end{array}$ & 268 & 457 & $\% 70,7$ & 7,0 & 11,3 & $\% 60,8$ & 38,2 & 40,6 & $\% 6,2$ \\
\hline $\begin{array}{l}\text { Enteral Diet } \\
\text { and } \\
\text { Medical } \\
\text { Nutrition }\end{array}$ & 309 & 441 & $\% 42,6$ & 31,0 & 35,1 & $\% 13,2$ & 10,0 & 12,6 & $\% 26,0$ \\
\hline Formula & 68 & 87 & $\% 29,4$ & 1,9 & 2,1 & $\% 8,2$ & 34,9 & 41,7 & $\% 19,6$ \\
\hline Others & 77 & 119 & $\% 53,8$ & 5,7 & 6,7 & $\% 18,6$ & 13,6 & 17,7 & $\% 29,6$ \\
\hline \multicolumn{4}{|c|}{ Total value for 6 months (Billion TL) } & \multicolumn{6}{|c|}{ Total Volume for 6 Months (Billion Boxes) } \\
\hline $\begin{array}{l}\text { Jan- June } \\
\text { Medical }\end{array}$ & 2019 & 2020 & Change & 2019 & 2020 & Change & 2019 & 2020 & Change \\
\hline $\begin{array}{l}\text { Products } \\
\text { Market }\end{array}$ & $1.439,4$ & $2.021,6$ & $\% 40,5$ & 87,2 & 100,6 & $\% 15,4$ & 16,5 & 20,1 & $\% 21,7$ \\
\hline $\begin{array}{l}\text { Nutritional } \\
\text { Supplement }\end{array}$ & 524,3 & 777,2 & $\% 48,2$ & 13,2 & 18,1 & $\% 37,3$ & 39,9 & 43,0 & $\% 7,9$ \\
\hline $\begin{array}{l}\text { Enteral Diet } \\
\text { and } \\
\text { Medical } \\
\text { Nutrition }\end{array}$ & 661,3 & 897,7 & $\% 35,7$ & 61,3 & 68,6 & $\% 12$ & 10,8 & 13,1 & $\% 21,2$ \\
\hline Formula & 129 & 175,5 & $\% 36$ & 3,7 & 4,1 & $\% 11,3$ & 35,1 & 42,9 & $\% 22,2$ \\
\hline Others & 124,7 & 171,3 & $\% 37,3$ & 9,1 & 9,8 & $\% 8,3$ & 13,7 & 17,4 & $\% 26,8$ \\
\hline
\end{tabular}

Resource: İeis, 2020, p.5

The average price of nutritional supplements was 40.6 TL in 2020 and the average price of formulas was 41.7 TL. In the first half of 2020, there was $40,5 \%$ growth in comparison to the same period in the previous year and a value of $2.021,6$ million TL, $15.4 \%$ increase in boxes with a volume of 100.6 million box volume. The average price of these products is 20,1 TL. In 2020, of non-pharmacologic products with a volume of 100.6 million boxes; 68.6 million belongs to enteral nutrition and medical nutrition. The average price for such products subject to reference price system like medication licensed by the Ministry of Health is 13.1 TL. Therefore, it is influential in setting the average price of medical products as $20.1 \mathrm{TL}$. The average price of nutritional supplements was 43 TL and the average price of formulas was 42.9 TL during the same period. 
Table 7. Pharmaceutical Foreign Trade (2019)

\begin{tabular}{|c|c|c|c|c|c|c|c|}
\hline $\begin{array}{l}\text { Million US } \\
\text { Dollar }\end{array}$ & 2018 & $\begin{array}{l}\text { March } \\
2018\end{array}$ & $\begin{array}{l}\text { March } \\
2019\end{array}$ & Change & $\begin{array}{l}\text { April } 2017 \\
\text { March } \\
2018\end{array}$ & $\begin{array}{l}\text { April } 2018 \\
\text { March } \\
2019\end{array}$ & Change \\
\hline Turkish Export & 167.945 & 41.136 & 42.249 & $\% 2,7$ & 160.320 & 139.047 & $\% 5,4$ \\
\hline $\begin{array}{l}\text { Pharmaceutical } \\
\text { Export }\end{array}$ & 1.173 & 288 & 273 & $\%-5,1$ & 1.003 & 1.158 & $\% 15,4$ \\
\hline $\begin{array}{l}\text { Pharmaceutical } \\
\text { Share }\end{array}$ & $\% 0,70$ & $\% 0,7$ & $\% 0,6$ & & $\% 0,6$ & $\% 0,7$ & \\
\hline Turkish Import & 223.046 & 61.895 & 49.020 & $\%-20,8$ & 245.259 & 210.173 & $\%-14,3$ \\
\hline $\begin{array}{l}\text { Pharmaceutical } \\
\text { Import }\end{array}$ & 5.003 & 1.451 & 1.343 & $\%-7,4$ & 5.278 & 4.896 & $\%-7,2$ \\
\hline $\begin{array}{l}\text { Pharmaceutical } \\
\text { Share }\end{array}$ & $\% 2,24$ & $\% 2,3$ & $\% 2,7$ & & $\% 2,2$ & $\% 2,3$ & \\
\hline $\begin{array}{l}\text { Turkish Foreign } \\
\text { Trade Volume }\end{array}$ & 390.992 & 103.030 & 91.269 & $\%-11,4$ & 405.580 & 379.220 & $\%-6,5$ \\
\hline $\begin{array}{l}\text { Pharmaceutical } \\
\text { Foreign Trade } \\
\text { Volume }\end{array}$ & 6.176 & 1.739 & 1.616 & $\%-7,1$ & 6.281 & 6.053 & $\%-3,6$ \\
\hline $\begin{array}{l}\text { Pharmaceutical } \\
\text { Share }\end{array}$ & $\% 1,58$ & $\% 1,7$ & $\% 1,8$ & & $\% 1,5$ & $\% 1,6$ & \\
\hline $\begin{array}{l}\text { Turkish Foreign } \\
\text { Trade Deficit }\end{array}$ & -55.100 & -20.759 & -6.771 & $\%-67,4$ & -84.939 & -41.126 & $\%-51,6$ \\
\hline $\begin{array}{l}\text { Pharmaceutical } \\
\text { Foreign Trade } \\
\text { Deficit }\end{array}$ & -3.830 & -1.163 & -1.070 & $\%-8$ & -4.275 & -3.738 & $\%-12,6$ \\
\hline $\begin{array}{l}\text { Pharmaceutical } \\
\text { Share }\end{array}$ & $\% 6,95$ & $\% 5,6$ & $\% 15,8$ & & $\% 5$ & $\% 9,1$ & \\
\hline $\begin{array}{l}\text { Turkish Import / } \\
\text { Export }\end{array}$ & $\% 75,30$ & $\% 66,5$ & $\% 86,2$ & & $\% 65,4$ & $\% 80,4$ & \\
\hline $\begin{array}{l}\text { Pharmaceutical } \\
\text { Import / Export }\end{array}$ & $\% 23,44$ & $\% 19,9$ & $\% 20,4$ & & $\% 19$ & $\% 23,6$ & \\
\hline $\begin{array}{l}\text { Million US } \\
\text { Dollar }\end{array}$ & 2018 & $\begin{array}{l}\text { Jan-June } \\
2018\end{array}$ & $\begin{array}{l}\text { Jan- June } \\
2019\end{array}$ & Change & $\begin{array}{l}\text { July } 2017 \\
\text { June } 2018\end{array}$ & $\begin{array}{l}\text { July } 2018 \\
\text { June } 2019\end{array}$ & Change \\
\hline Turkish Export & $167.920,8$ & $82.163,2$ & $83.716,4$ & $\% 1,9$ & $161.780,5$ & $169.473,8$ & $\% 4,8$ \\
\hline $\begin{array}{l}\text { Pharmaceutical } \\
\text { Export }\end{array}$ & $1.172,4$ & 599 & 621,7 & $\% 3,8$ & $1.130,8$ & 1.195 & $\% 5,7$ \\
\hline $\begin{array}{l}\text { Pharmaceutical } \\
\text { Share }\end{array}$ & $\% 0,70$ & $\% 0,73$ & $\% 0,74$ & & $\% 0,70$ & $\% 0,71$ & \\
\hline Turkish Import & $223.047,2$ & $122.966,8$ & $98.565,8$ & $\%-19,8$ & $248.446,6$ & $198.646,1$ & $\%-20$ \\
\hline $\begin{array}{l}\text { Pharmaceutical } \\
\text { Import }\end{array}$ & $5.003,4$ & $2.769,5$ & $2.589,7$ & $\%-6,5$ & $5.446,6$ & $4.823,6$ & $\%-11,4$ \\
\hline $\begin{array}{l}\text { Pharmaceutical } \\
\text { Share }\end{array}$ & $\% 2,2$ & $\% 2,3$ & $\% 2,6$ & & $\% 2,2$ & $\% 2,4$ & \\
\hline $\begin{array}{l}\text { Turkish Foreign } \\
\text { Trade Volume } \\
\text { Pharmaceutical }\end{array}$ & 390.968 & 205.130 & $182.282,2$ & $\%-11,1$ & $410.227,1$ & $368.119,9$ & $\%-0,3$ \\
\hline $\begin{array}{l}\text { Foreign Trade } \\
\text { Volume }\end{array}$ & $6.175,8$ & $3.368,6$ & $3.211,5$ & $\%-4,7$ & $6.577,4$ & $6.018,6$ & $\%-8,5$ \\
\hline $\begin{array}{l}\text { Pharmaceutical } \\
\text { Share }\end{array}$ & $\% 1,6$ & $\% 1,64$ & $\% 1,76$ & & $\% 1,60$ & $\% 1,63$ & \\
\hline $\begin{array}{l}\text { Turkish Foreign } \\
\text { Trade Deficit } \\
\text { Pharmaceutical }\end{array}$ & $-55.126,4$ & $-40.803,7$ & $-14.849,5$ & $\%-63,6$ & $-86.666,1$ & $-29.172,3$ & $\%-66,3$ \\
\hline $\begin{array}{l}\text { Foreign Trade } \\
\text { Deficit }\end{array}$ & -3.831 & $-2.170,5$ & -1.968 & $\%-9,3$ & $-4.315,7$ & $-3.628,5$ & $\%-15,9$ \\
\hline Pharmaceutical & $\% 6,9$ & $\% 5,32$ & $\% 13,25$ & & $\% 4,98$ & $\% 12,44$ & \\
\hline
\end{tabular}




\begin{tabular}{|c|c|c|c|c|c|c|c|}
\hline $\begin{array}{l}\text { Share } \\
\text { Turkish Import / } \\
\text { Export }\end{array}$ & $\% 75,3$ & $\% 66,8$ & $\% 84,9$ & & $\% 65,1$ & $\% 85,3$ & \\
\hline $\begin{array}{l}\text { Pharmaceutical } \\
\text { Import / Export }\end{array}$ & $\% 23,4$ & $\% 21,6$ & $\% 24$ & & $\% 20,8$ & $\% 24,8$ & \\
\hline $\begin{array}{l}\text { US Million } \\
\text { Dollar }\end{array}$ & 2018 & Sept 2018 & Sept 2019 & Change & $\begin{array}{l}\text { Jan-Sept } \\
2018\end{array}$ & $\begin{array}{l}\text { Jan- June } \\
2020\end{array}$ & Change \\
\hline Turkish Export & $167.920,8$ & 14.398 & 14.436 & $\% 0,3$ & 122.942 & 125.765 & $\% 2,3$ \\
\hline $\begin{array}{l}\text { Pharmaceutical } \\
\text { Export }\end{array}$ & $1.172,4$ & 92 & 108 & $\% 17,4$ & 847 & 875,9 & $\% 5,4$ \\
\hline $\begin{array}{l}\text { Pharmaceutical } \\
\text { Share }\end{array}$ & $\% 0,7$ & $\% 0,6$ & $\% 0,7$ & & $\% 0,7$ & $\% 0,7$ & \\
\hline Turkish Import & $223.047,2$ & 16.327 & 16.492 & $\% 1$ & 174.155 & 148.428 & $\%-14,8$ \\
\hline $\begin{array}{l}\text { Pharmaceutical } \\
\text { Import }\end{array}$ & $5.003,4$ & 318 & 440 & $\% 38,3$ & 3.800 & 3.876 & $\% 2$ \\
\hline $\begin{array}{l}\text { Pharmaceutical } \\
\text { Share }\end{array}$ & $\% 2,2$ & $\% 1,9$ & $\% 2,7$ & & $\% 2,2$ & $\% 2,6$ & \\
\hline $\begin{array}{l}\text { Turkish Foreign } \\
\text { Trade Volume } \\
\text { Pharmaceutical }\end{array}$ & 390.968 & 30.724 & 30.928 & $\% 0,7$ & 297.097 & 274.193 & $\%-7,7$ \\
\hline $\begin{array}{l}\text { Foreign Trade } \\
\text { Volume }\end{array}$ & $6.175,8$ & 410 & 548 & $\% 33,6$ & 4.647 & 4.769 & $\% 2,6$ \\
\hline $\begin{array}{l}\text { Pharmaceutical } \\
\text { Share }\end{array}$ & $\% 1,6$ & $\% 1,3$ & $\% 1,8$ & & $\% 1,6$ & $\% 1,7$ & \\
\hline $\begin{array}{l}\text { Turkish Foreign } \\
\text { Trade Deficit }\end{array}$ & $-55.126,4$ & -1.929 & -2.056 & $\% 6,6$ & -51.213 & -22.664 & $\%-55,7$ \\
\hline $\begin{array}{l}\text { Pharmaceutical } \\
\text { Foreign Trade } \\
\text { Deficit }\end{array}$ & -3.831 & -226 & -332 & $\% 46,8$ & -2.953 & -2.984 & $\% 1$ \\
\hline $\begin{array}{l}\text { Pharmaceutical } \\
\text { Share }\end{array}$ & $\% 6,9$ & $\% 11,7$ & $\% 16,2$ & & $\% 5,8$ & $\% 13,2$ & \\
\hline $\begin{array}{l}\text { Turkish Import / } \\
\text { Export }\end{array}$ & $\% 75,3$ & $\% 88,2$ & $\% 87,5$ & & $\% 70,6$ & $\% 84,7$ & \\
\hline $\begin{array}{l}\text { Pharmaceutical } \\
\text { Import / Export }\end{array}$ & $\% 23,4$ & $\% 28,9$ & $\% 24,5$ & & $\% 22,3$ & $\% 23$ & \\
\hline
\end{tabular}

Resource: $\dot{\text { Ieis, } 2019, \text { p.6-7 }}$

During the first 3 months, pharmaceutical export decreased by $5.1 \%$ and became 273 million US dollar. Within that period, Turkish export increased by $2.7 \%$ and as a result, the pharmaceutical share in Turkish export became $0.6 \%$. On annual basis, pharmaceutical export increased $15.4 \%$ in comparison to the previous year and became 1.158 million US dollar. Within that period, Turkish export increased by $5.4 \%$. Following these developments, pharmaceutical foreign trade deficit became 3.738 million US Dollar and the ratio in which the export covers for the import was $23.6 \%$. During the first half of the year, pharmaceutical export had $3.8 \%$ increase and became 621.7 million US Dollar. Within that period, Turkish export had 1.9\% increase. The share of pharmaceutical export in Turkey's export became $0.74 \%$. On annual basis, pharmaceutical export 
increased by $5.7 \%$ in comparison to the previous year and became $1.195,0$ million US dollar. Within that period, Turkish export had $4.8 \%$ increase. Pharmaceutical export decreased $11.4 \%$ and became $4.823,6$ million US dollar. As a result of these developments, pharmaceutical foreign trade deficit became 3.628,5 million US dollar and the ratio in which the export covers for the import was 24.68\%. As of Eylul 2019, pharmaceutical export increased by $5.4 \%$ in comparison to the previous year and became 893 million US dollar for the last 9 months. Within that period, Turkish export increased by $2.3 \%$. Pharmaceutical export became 3.876 million US dollar. As a result of these developments, pharmaceutical foreign trade deficit became 2.984 million US dollar and the ratio in which the export covers for the import was $23 \%$.

Table 8. Pharmaceutical Foreign Trade (2020)

\begin{tabular}{|c|c|c|c|c|c|c|c|}
\hline $\begin{array}{l}\text { Million US } \\
\text { Dollar }\end{array}$ & 2019 & $\begin{array}{l}\text { March } \\
2019\end{array}$ & $\begin{array}{l}\text { March } \\
2020\end{array}$ & Change & $\begin{array}{l}\text { April } 2018 \\
\text { March } \\
2019\end{array}$ & $\begin{array}{l}\text { April } 2019 \\
\text { March } \\
2020\end{array}$ & Change \\
\hline Turkish Export & $180,848,6$ & $16.335,9$ & $13.422,0$ & $\%-17,8$ & $178.457,1$ & $179.054,2$ & $\% 0,3$ \\
\hline $\begin{array}{l}\text { Pharmaceutical } \\
\text { Export }\end{array}$ & $1.442,1$ & 124,0 & 164,1 & $\% 32,4$ & $1.288,8$ & $1.528,1$ & $\% 18,6$ \\
\hline $\begin{array}{l}\text { Pharmaceutical } \\
\text { Share }\end{array}$ & $\% 0,80$ & $\% 0,76$ & $\% 1,22$ & & $\% 0,72$ & $\% 0,85$ & \\
\hline Turkish Import & $210.344,3$ & $18.250,5$ & $18.813,4$ & $\% 3,1$ & $217.307,7$ & $215.526,9$ & $\%-0,8$ \\
\hline $\begin{array}{l}\text { Pharmaceutical } \\
\text { Import }\end{array}$ & $5.555,5$ & 526,3 & 550,5 & $\% 4,6$ & $5.007,8$ & $5.654,0$ & $\% 12,9$ \\
\hline $\begin{array}{l}\text { Pharmaceutical } \\
\text { Share }\end{array}$ & $\% 2,64$ & $\% 2,88$ & $\% 2,93$ & & $\% 2,30$ & $\% 2,62$ & \\
\hline $\begin{array}{l}\text { Turkish Foreign } \\
\text { Trade Volume } \\
\text { Pharmaceutical }\end{array}$ & $391.192,9$ & $34.586,4$ & $32.235,5$ & $\%-6,8$ & $395.764,8$ & $394.581,1$ & $\%-0,3$ \\
\hline $\begin{array}{l}\text { Foreign Trade } \\
\text { Volume }\end{array}$ & $6.997,6$ & 650,2 & 714,6 & $\% 9,9$ & $6.296,6$ & $7.182,1$ & $\% 14,1$ \\
\hline $\begin{array}{l}\text { Pharmaceutical } \\
\text { Share }\end{array}$ & $\% 1,79$ & $\% 1,88$ & $\% 2,22$ & & $\% 1,59$ & $\% 1,82$ & \\
\hline $\begin{array}{l}\text { Turkish Foreign } \\
\text { Trade Deficit } \\
\text { Pharmaceutical }\end{array}$ & $-29.495,7$ & $-1.914,6$ & $-5.319,4$ & $\% 181,6$ & $-38.850,6$ & $-36.472,7$ & $\%-6,1$ \\
\hline $\begin{array}{l}\text { Foreign Trade } \\
\text { Deficit }\end{array}$ & $-4.113,4$ & $-402,3$ & $-386,4$ & $\%-4,0$ & $-3.719,1$ & $-4.125,9$ & $\%-10,9$ \\
\hline $\begin{array}{l}\text { Pharmaceutical } \\
\text { Share }\end{array}$ & $\% 13,9$ & $\% 21,01$ & $\% 7,17$ & & $\% 9,57$ & $\% 11,31$ & \\
\hline $\begin{array}{l}\text { Turkish Import / } \\
\text { Export }\end{array}$ & $\% 75,3$ & $\% 66,8$ & $\% 84,9$ & & $\% 65,1$ & $\% 85,3$ & \\
\hline $\begin{array}{l}\text { Pharmaceutical } \\
\text { Import / Export }\end{array}$ & $\% 26$ & $\% 23,6$ & $\% 29,8$ & & $\% 25,7$ & $\% 27$ & \\
\hline $\begin{array}{l}\text { Million US } \\
\text { Dollar }\end{array}$ & 2019 & June 2019 & June 2020 & Change & $\begin{array}{c}\text { January- } \\
\text { June } 2019\end{array}$ & $\begin{array}{l}\text { January- } \\
\text { June } 2020\end{array}$ & Change \\
\hline Turkish Export & $180,848,6$ & $11.634,7$ & $13.462,2$ & $\% 15,7$ & $88.364,1$ & $75.020,6$ & $\%-15,1$ \\
\hline Pharmaceutical & $1.442,1$ & 111,5 & 162,0 & $\% 45,3$ & 686,0 & 875,9 & $\% 27,7$ \\
\hline
\end{tabular}


Pandemics in the History of Medicine and Variations of Pharmaceutical Market in Turkey

During the Era of the Recent Covid-19 Corona Pandemic

\begin{tabular}{|c|c|c|c|c|c|c|c|}
\hline Export & & & & & & & \\
\hline $\begin{array}{l}\text { Pharmaceutical } \\
\text { Share }\end{array}$ & $\% 0,80$ & $\% 0,96$ & $\% 1,20$ & & $\% 0,78$ & $\% 1,17$ & \\
\hline Turkish Import & $210.344,3$ & $15.064,5$ & $16.307,8$ & $\% 8,3$ & $102.151,8$ & $98.894,8$ & $\%-3,2$ \\
\hline $\begin{array}{l}\text { Pharmaceutical } \\
\text { Import }\end{array}$ & $5.555,5$ & 360,8 & 422,6 & $\% 17,1$ & $2.669,3$ & $2.830,7$ & $\% 6$ \\
\hline $\begin{array}{l}\text { Pharmaceutical } \\
\text { Share }\end{array}$ & $\% 2,64$ & $\% 2,40$ & $\% 2,59$ & & $\% 2,61$ & $\% 2,86$ & \\
\hline $\begin{array}{l}\text { Turkish Foreign } \\
\text { Trade Volume }\end{array}$ & $391.192,9$ & $26.669,1$ & $29.769,9$ & $\% 11,5$ & 190.516 & $173.915,4$ & $\%-8,7$ \\
\hline $\begin{array}{l}\text { Pharmaceutical } \\
\text { Foreign Trade } \\
\text { Volume }\end{array}$ & $6.997,6$ & 472,3 & 584,6 & $\% 23,8$ & $3.355,3$ & $3.706,6$ & $\% 10,5$ \\
\hline $\begin{array}{l}\text { Pharmaceutical } \\
\text { Share }\end{array}$ & $\% 1,79$ & $\% 1,77$ & $\% 1,96$ & & $\% 1,76$ & $\% 2,13$ & \\
\hline $\begin{array}{l}\text { Turkish Foreign } \\
\text { Trade Deficit }\end{array}$ & $-29.495,7$ & $-3.429,8$ & $-2.845,6$ & $\%-17$ & $-13.787,7$ & $-23.874,2$ & $\% 73,2$ \\
\hline $\begin{array}{l}\text { Pharmaceutical } \\
\text { Foreign Trade } \\
\text { Deficit }\end{array}$ & $-4.113,4$ & $-318,4$ & $-260,6$ & $\%-18,2$ & $-1.983,2$ & $-1.954,8$ & $\%-1,4$ \\
\hline $\begin{array}{l}\text { Pharmaceutical } \\
\text { Share }\end{array}$ & $\% 13,9$ & $\% 9,28$ & $\% 9,16$ & & $\% 14,38$ & $\% 8,19$ & \\
\hline $\begin{array}{l}\text { Turkish Import / } \\
\text { Export }\end{array}$ & $\% 86$ & $\% 77,2$ & $\% 82,6$ & & $\% 86,5$ & $\% 75,9$ & \\
\hline $\begin{array}{l}\text { Pharmaceutical } \\
\text { Import / Export }\end{array}$ & $\% 26$ & $\% 30,9$ & $\% 38,3$ & & $\% 25,7$ & $\% 30,9$ & \\
\hline $\begin{array}{l}\text { Million US } \\
\text { Dollar }\end{array}$ & 2019 & $\begin{array}{l}\text { September } \\
2019\end{array}$ & $\begin{array}{l}\text { September } \\
2020\end{array}$ & Change & $\begin{array}{l}\text { January- } \\
\text { Septe.2019 }\end{array}$ & $\begin{array}{l}\text { January- } \\
\text { Sept. } 2020\end{array}$ & Change \\
\hline Turkish Export & $180,848,6$ & $15.273,6$ & $16.009,2$ & $\% 4,8$ & $132.792,6$ & $118.324,8$ & $\%-10,9$ \\
\hline $\begin{array}{l}\text { Pharmaceutical } \\
\text { Export }\end{array}$ & $1.442,1$ & 115,2 & 153,9 & $\% 33,6$ & 981,5 & $1.307,1$ & $\% 33,2$ \\
\hline $\begin{array}{l}\text { Pharmaceutical } \\
\text { Share }\end{array}$ & $\% 0,80$ & $\% 0,75$ & $\% 0,96$ & & $\% 0,74$ & $\% 1,10$ & \\
\hline Turkish Import & $210.344,3$ & $16.940,6$ & $20.836,9$ & $\% 23$ & $153.885,3$ & $156.186,4$ & $\% 1,5$ \\
\hline $\begin{array}{l}\text { Pharmaceutical } \\
\text { Import }\end{array}$ & $5.555,5$ & 445,8 & 546,7 & $\% 22,6$ & 3.991 & $4.125,4$ & $\% 3,4$ \\
\hline $\begin{array}{l}\text { Pharmaceutical } \\
\text { Share }\end{array}$ & $\% 2,64$ & $\% 2,63$ & $\% 2,62$ & & $\% 2,59$ & $\% 2,64$ & \\
\hline $\begin{array}{l}\text { Turkish Foreign } \\
\text { Trade Volume } \\
\text { Pharmaceutical }\end{array}$ & $391.192,9$ & $32.214,2$ & $36.846,2$ & $\% 14,4$ & $286.677,9$ & $274.511,2$ & $\%-4,2$ \\
\hline $\begin{array}{l}\text { Foreign Trade } \\
\text { Volume }\end{array}$ & $6.997,6$ & 561 & 700,6 & $\% 24,9$ & $4.972,5$ & $5.432,4$ & $\% 9,3$ \\
\hline $\begin{array}{l}\text { Pharmaceutical } \\
\text { Share }\end{array}$ & $\% 1,79$ & $\% 1,74$ & $\% 1,90$ & & $\% 1,73$ & $\% 1,98$ & \\
\hline $\begin{array}{l}\text { Turkish Foreign } \\
\text { Trade Deficit } \\
\text { Pharmaceutical }\end{array}$ & $-29.495,7$ & $-1.667,1$ & $-4.827,7$ & $\% 189,6$ & $-21.092,8$ & $-37.861,6$ & $\% 79,5$ \\
\hline $\begin{array}{l}\text { Foreign Trade } \\
\text { Deficit }\end{array}$ & $-4.113,4$ & $-318,4$ & $-392,9$ & $\% 23,4$ & $-3.009,5$ & $-2.818,3$ & $\%-6,4$ \\
\hline $\begin{array}{l}\text { Pharmaceutical } \\
\text { Share }\end{array}$ & $\% 13,9$ & $\% 19,10$ & $\% 8,14$ & & $\% 14,27$ & $\% 7,44$ & \\
\hline $\begin{array}{l}\text { Turkish Import / } \\
\text { Export }\end{array}$ & $\% 86$ & $\% 90,2$ & $\% 76,8$ & & $\% 86,3$ & $\% 75,8$ & \\
\hline $\begin{array}{l}\text { Pharmaceutical } \\
\text { Import / Export }\end{array}$ & $\% 26$ & $\% 25,8$ & $\% 28,1$ & & $\% 24,6$ & $\% 31,7$ & \\
\hline
\end{tabular}

Resource: İeis, 2020, s.6-7 
In March 2020, pharmaceutical export became 1.528.1 million US dollar with $18.6 \%$ increase. Within that period, Turkish export increased $0.3 \%$. The share of pharmaceutical export in Turkish export became $0.74 \%$. Pharmaceutical export increased $32.4 \%$ in comparison to the same period in the previous year and became 164.1 million US dollar. Pharmaceutical export increased $12.9 \%$ and became 5.654 million US dollar. As a result of these developments, pharmaceutical foreign trade deficit became 4.126 million US dollar and the ratio in which the export covers for the import was $27 \%$. According to TUIK overall trade system calculation method in 2020 June, pharmaceutical export increased by $45,3 \%$ in comparison to the previous year and became 162 million US dollar. Within that period, Turkish export increased 15.7\%. During the first 6 months in 2020, Turkish export decreased by $15.1 \%$ and pharmaceutical export increased $27.7 \%$ and became 875,9 million US dollar. Within that period, pharmaceutical export increased $6 \%$ and became 2.830,7 million US dollar. During the first 6 months, the ratio in which the pharmaceutical export covers for the import increased by 5.2 points and reached up to $30,9 \%$. As of June 2020, pharmaceutical export for 12 months increased by $23 \%$ in comparison to the previous year and became $1.632,0$ million US Dollar. Within that period, Turkish export decreased $6.4 \%$. Pharmaceutical export increased by $15.5 \%$ and became 5.716,9 million US Dollar. As a result of these developments, pharmaceutical foreign trade deficit became 4.085,0 million US dollar and the ratio in which the export covers for the import was $28,5 \%$. While the pharmaceutical export was 981,5 million dollars from January to September 2019, it reached up to 1.307,1 million dollars from January to September 2020. There was 33,2\% increase in pharmaceutical export figures. The pharmaceutical import was 3.991 million dollars from January to September 2019. This figure increased by $3,4 \%$ and reached up to $4.125,4$ million dollars.

\section{Discussion}

It is obligatory to have a strong pharmaceutical industry and pharmaceutical market to introduce medical services effectively and to preserve overall health. In addition to its contributions to the economic 
growth, the pharmaceutical industry and market is also necessary for a country so that medication can be manufactured even at times of such disasters as epidemics, pandemics, war, and embargo. Turkey also imports some medication as many other countries do. Imported medication includes antidote, cancer medication, insulin, hormone medication, some ophthalmologic preparations (İlaç Sektörü Raporu 2019, p.6). Covid-19 has impacted the pharmaceutical industry and market. There has been an increase in the usage of some medication such as analgesics for the treatment of Covid-19 patients. Patients with therapeutic cases such as autoimmune diseases continue to receive their medication. Therapeutical medications are not the ones taken in acute illnesses or at the hospital. Therefore, Covid-19 did not have any influence on the purchase of these medication. Such areas as dermatology and ophthalmology work on polyclinical basis and therefore, significant decline has been observed in optional departments. One of the greatest impacts of Covid-19 on the public and private sector has been the economy packages declared by the governments for Covid19 period (Ural, Eren, Sağl1, 2020, p.3-4). As of January 1st, 2021, total Covid-19 related mortality rate has been 20.881 in Turkey and the number of patients requiring intensive care is 3.918. The number of cured patients is 2.208.652. On a global scale, total number of people who lost their lives due to Covid-19 pandemic is 1,825.709 and the number of active cases is 22.659.240 (wikipedia, 2021).

Considering pharmaceutical market, imported, and exported medication, pharmaceutical import and export rates and pharmaceutical foreign trade volume during the pandemic, Turkish pharmaceutical market used to be TL 29.5 billion in January to September 2019 and it increased by $17.4 \%$ in January to September 2020 and became TL 34,6 billion. In the exported and imported pharmaceutical market, Turkey sold imported goods of TL 13.8 billion in the first 9 months of 2019 . During the first 9 months of 2020, there has been $22.2 \%$ increase with a sales figure of TL 16.9 billion. During the first 9 months of 2019, there was a sale of TL 15,7 billion imported goods. During the first 9 months of 2020 , there was a sale of TL 17,7 billion with an increase rate of $13,1 \%$. From January to September 2019, the pharmaceutical export was 981.5 billion dollars while it became 1.307,1 million dollars from June to 
September 2020. This accounts for an increase of 33,2\%. Pharmaceutical export was 3.991 million dollars from January to September 2019, 4.125,4 million dollars from January to September 2020 with an increase of 3,4\%. Pharmaceutical foreign trade volume was 4.972,5 million dollars in Turkey from January to September 2019. This increased by $9.3 \%$ and reached up to 5.432,4 million dollars from January to September 2020.

\section{References}

Açıkel C. (2014). 2014 Yılının en büyük salgını: Ebola virüs hastalığı. Gülhane Tip Dergisi, 56, 194-197.

Ayati, N., Saiyarsarai P. and Nikfar S. (2020). Short and long term impacts of COVID-19 on the pharmaceutical sector. Daru Journal of Pharmaceutical Sciences, 28(1), 1-7.

Bingül Ak, B., Türk, A. and Ak, R. (2020). Covıd-19 bağlamında tarihteki büyük salgınlar ve ekonomik sonuçları. Turkish Studies, 15(4), 189200.

Cameron, M.J., Kelvin, A.A., Leon, A.J., Cameron, C.M., Ran, L., Xu, L., Chu, Y.K., Danesh, A., Fang, Y., Li, Q., Anderson, A., Couch, R.C., Paquette, S.G., Fomukong, N.G., Kistner, O., Lauchart, M., Rowe, T., Harrod, K.S., Jonsson, C.B. and Kelvin, D.J. (2012). Lack of innate interferon responses during sars coronavirus infection in a vaccination and reinfection ferret model. Plos One, 7(9), e45842.

Cinel E. A. (2020). Covid-19'un küresel makroekonomik etkileri ve beklentiler. Politik Ekonomik Kuram, 4(1), 124-140.

Çınar F. and Oğuz M. (2020). Türkiye'nin Covid-19 pandemisine yönelik stratejilerinin SWOT analizi ile değerlendirilmesi. Sağlık ve Sosyal Refah Araştırmaları Dergisi, 2(2), 1-11.

Çoban O., Coşkun Ö. and Çoban A. (2020). Covid-19 krizinin finansal piyasalara etkisi: Türkiye örneği. Gaziantep University Journal Of Social Sciences, (Special Issue), 506-519.

Demir İ. (2020). Kovid-19 salgının seyri ve Türkiye ekonomisi, Kovid-19 (Koronavirüs) salgınının ekonomik etkileri. Uluslararası İlişkiler ve Stratejik Araştırmalar (ULISA) Enstitüsü (Ulisa), Ankara Yıldırım Beyazıt Üniversitesi.

Duran M. and Acar M. (2020). Bir virüsün dünyaya ettikleri: Covid-19 pandemisinin makroekonomik etkileri. International Journal of Social and Economic Sciences, 10(1), 54-67. 
Eyigün C. (2005). Ortaya çıkışından bugüne Sars: Güncel durum. Flora Dergisi, 10(3), 108-118.

ILO Sectoral Brief. (2020). Covid-19 And the Health Sector. International Labour

Organization, https://www.ilo.org/sector/Resources/publications/WCMS 741655/lang-en/index.htm. (28.12.2020)

İlaç Sektörü Raporu. (2019). Sanayi ve Teknoloji Bakanlığı, Sanayi ve Verimlilik Genel Müdürlüğü sektörel raporlar ve analizler serisi. ieis.org.tr. (21.12.2020)

İlaç ve Eczacılık Ürünleri Sektörü-Sektör Raporları. (2020). Ticaret Bakanlığı, İhracat Genel Müdürlüğü. İlaç ve Eczacılık Ürünleri Sektörü ticaret.gov.tr. (12.11.2020)

İlaç Sektörel Bakış, (2020). KPMG. Sektörel Bakıș 2020 - İlac - KPMG Türkiye home.kpmg. (16.10.2020)

Kaynak S. (2016). Türk ilaç sektörünün rekabet yapısı ve yoğunlaşma analizi. Çankırı Karatekin Üniversitesi İktisadi ve İdari Bilimler Fakültesi Dergisi, 6(2), 49-66.

Nakiboğlu A. and Işık S. (2020). Kovid-19 Salgınının ekonomi üzerindeki etkileri: Türkiye'de işletme sahipleri üzerinde bir araştırma. Turkish Studies, 15(4), 76

Özdemir H., Atak O. and Hatıper Z. (2020). Koronavirüs (Covid-19) küresel salgını dolayısıyla Türkiye ve bazı gelişmiş ülkelerde alınan ekonomik ve mali tedbirler. Vergi Raporu, 248, 186-200.

Sağlı A., Eren U., Ural A. (2020). Covid-19 Krizinin Türkiye'de ve globalde sağlık sektörüne etkileri. Sağlık Sektöründeki Son Gelişmeler Toplantı Raporu. wwww.assets.ey.com. (23.05.2021)

Taş, M. B. H. and Yağanoğlu, M. (2020). Ağır akut solunum yolu yetersizliği sendromu Koronavirüsü 2 (SARSCoV-2) dünya çapındaki analizi ve gelecekteki durumu. Avrupa Bilim ve Teknoloji Dergisi, 20, 248-253.

Tokaç M. (2020). Salgın hastalıkların tarihi, SD Platform Dergisi, www.sdplatform.com. (23.05.2020)

Türk A., Ak Bingül B. and Ak R., (2020), Tarihsel süreçte yaşanan pandemilerin ekonomik ve sosyal etkileri. Gaziantep University Journal of Social Sciences, Special Issue, 612-632.

Türkiye İlaç Sanayi Sektör Raporu. (2008). Veriler. Türkiye Odalar ve Borsalar Birliği Türkiye İlaç Sanayi Meclisi. ieis.org.tr. (23.05.2021) 
Yıldırım H. (2015). Batı Afrika ekonomisinde Ebola etkisi. EkoAvrasya, Avrasya Ekonomik İlişkiler Derneği, Ankara. wwww.ekoavrasya.net. (09.10.2020)

Zeren D. and Boynukısa M. (2020). Covid-19 sürecinde beşeri ilaç sektörünün sektör yöneticilerinin perspektifinden değerlendirilmesi ve pandemi sonrasına yönelik projeksyonlar. Journal of Management Theory and Practices Research, 1, 26-44.

\section{Kaynakça Bilgisi / Citation Information}

Güven, E. (2021). Pandemics in the history of medicine and variations of pharmaceutical market in Turkey during the era of the recent covid-19 corona pandemic. OPUS- International Journal of Society Studies, 18(40), 2030-2055. DOI: 10.26466/opus.907864. 